SEFAD, 2018 (40): 61-72

e-ISSN: 2458-908X

DOI Number: https://dx.doi.org/10.21497/sefad.515032

\title{
Sa‘di-yi Şîrâzî’nin Yolculuklarının “Gülistân” Eseri Üzerindeki Etkileri
}

Öz

\author{
Dr. Gamze Gizem Avcioğlu \\ Selçuk Üniversitesi Edebiyat Fakültesi \\ Fars Dili ve Edebiyatı Bölümü \\ gmzavcioglu@selcuk.edu.tr
}

XIII. yüzyılda yaşayan Sa'di-yi Şîrâzî (öl. 691/1292), adı günümüze kadar ulaşan İran'ın en büyük şairlerindendir. Yaklaşan Moğol istilası nedeniyle eğitim görmek için Bağdat'a giden ve oradan da uzun bir yolculuğa çıkan şair yaşadığı dönemin siyasî-sosyal olaylarını içinde barındıran önemli eserler kaleme almıştır. Bu eserler arasında adından en çok bahsettiren "Bûstân" ve "Gülistân"dır. "Bûstân" 655/1257 yılında mütekârib bahrinde yazılmıştır. 5000 beyitten oluşan didaktik bir manzumedir. Diğer eseri "Gülistân" ise "Bûstân"dan bir yıl sonra 656/1258 yılında yazılmıştır. Nazım ve nesrin iç içe olduğu bu eser, Sa'dî'nin diğer eserlerinden üslûp ve içerik açısından ayrılarak hemen hemen her şairin rahle-i tedrisinden geçmiştir. "Gülistân" Sa'dî'nin hayatından anekdotlar sunması ve yaşadığı deneyimleri okuyucuya aktarması açısından önemli bir eserdir. "Gülistân"da anlatılan hikâyelerin çoğu, şairin uzun yolculukları sırasında karşılaştığ 1 kişilerden ve başına gelen olaylardan edindiği tecrübeler üzerinedir. Bu çalışmamızda Şîrâz'ın içinde bulunduğu karmaşa sebebiyle ülkesinden ayrılan Sa'dî'nin "Gülistân" eserinde dile getirdiği uzun yolculuklar ele alınacak ve bu yolculukların "Gülistân"da nasıl işlendiği üzerinde durulacaktır.

Anahtar Kelimeler: Sa’di-yi Şîrâzî, Gülistân, yolculuk.

\section{The Effects of Sa'di-yi Şîrâzî's Journeys on His Work “Gülistân"}

\section{Abstract}

Sa'di-yi Şîrâzî (d.691/1292), who lived in the XIII. Century and whose name has reached the present day, is one of the greatest poets of Iran. The poet, who went to Baghdad for a training trip due to the upcoming Mongol invasion and took a long journey then, wrote up important works containing the political-social events of his time. Among these works, "Bustân" and "Gulistan" are the ones which make an indelible impression most. "Bûstân" was written in the year of 655/1257 in the pattern of mütekârib bahri (a poem pattern). It is a didactic poem consisting of 500 couplets. His other work "Gülistân" was written in the year of 656/1258, a year after "Bûstân". This work in which poetry and prose are intertwined vary from the other works of Sa'dî in terms of style and content and it has been studied and thought on by almost all poets. "Gülistân" is an important work in terms of presenting anecdotes from Sa'dî's life and transferring his experiences to the reader. Most of the stories described in "Gülistân" are about the experiences that the poets gained during his long journeys and the events that happened. This study is intended to deal with the long journeys mentioned by Sa'dî' in "Gülistân" after he left his country due to the chaos in Şîrâz. The effects of these journeys on "Gülistân" will also be emphasized.

Keywords: Sa'di-yi Şîrâzî, Gülistân, journey. 


\section{GİRIŞ}

Sa'di-yi Şîrâzî, uzun süren taht kavgaları sonucu Sa'd b. Zengî'nin Fars bölgesinin hâkimiyetini ele geçirdiği dönemde, Şîrâz'da dünyaya gelmiştir. Küçük yaşta babasını kaybeden Sa'dî, ilk eğitimini babasının yanında almıştır (Beyânî 1388: III/655).

Şairin gençlik yılları İran'a yapılan Moğol saldırılarının başladığı zamana denk gelmiştir (Dânişpejûh 1388: 19-20). Bu saldırılar, Sa'dî'nin vatanı olan Şîrâz'dan iki defa ayrılmasına neden olmuştur. Bunlardan ilki, eğitim görmek için Bağdat'a gitmesidir. (İmdâd [t.y.]: 67) Burada bulunan Nizâmiye medresesinde dönemin ileri gelen hocalarından dersler almiştır (Zerrînkûb 1386: 15-16).

Eğitimini tamamladıktan sonra Şam, Hicaz, Lübnan ve Rum tarafına uzun bir yolculuğa çıkmıştır. Sa'dî'nin 620-621/1223-1224 yılında başlayan bu yolculukları 655/1257 yılında Şîrâz'a dönmesi ile son bulmuştur (Safâ 1372: II/127). Sa'dî, bu yolculuklarından sadece Arapça ve Farsça gazelleriyle değil; aynı zamanda ilginç maceralar, düşünceler ve anılarla da dönmüştür (Zerrînkûb 1343: 232).

Sa’dî, Şîrâz'a döndükten bir yıl sonra 656/1258 yılında "Gülistân" eserini yazmıştır. Bu eser, sekiz bölümden oluşmaktadır ve üslûp açısından Sehl-i mümteni örneğidir (Yazıcı 1966: 38). Nazım ve nesrin bir arada olduğu didaktik bir eser olması nedeniyle Osmanlı dönemi medreselerinde ders kitabı olarak okutulmuş, çeşitli dünya dillerine ve Türkçeye defalarca çevrilmiştir.

Sa'dî'nin "Gülistân"da konu aldığı hikâyelerin bir kısmı kendi müşahedelerine bir kısmı da duyduklarına ve okuduklarına dayanmaktadır (Yazıcı 1966: 38). Aynı zamanda çıtığı uzun yolculuklardan edindiği tecrübeleri de en yalın şekliyle okuyucuya aktarmaktadır.

Sa'dî'nin Şîrâz'dan ikinci kez ayrılmasına neden olan olay, Salgurlular'ın gerilemesi ve Moğollar'ın Şînâz'ı tekrar istilâ etmesidir. Bu olay üzerine tekrar yolculuğa çıkan Sa'dî 662/1264 yılında Bağdat'a, oradan da hac için Mekke'ye gitmiştir. Dönüşte Tebriz'e uğramış burada Hace Şemseddîn Cuveynî ve kardeşi Atâ Melîk Cuveynî tarafından iyi karşılanmıştır (Şîrâzlı Şeyh Sa'dî 2011: 17). Bir süre sonra Şîrâz'a geri dönen Sa'dî'nin ömrünün son yıllarını burada ibadet ve riyazetle geçirdiği anlaşılmaktadır (Yazıcı 1966: 37).

Tüm bu bilgiler ışığında çalışmamızda Sa'dî'nin yolculukları esnasında karşılaştığı kişilerin ya da durumların "Gülistân" eseri üzerinde bıraktı̆̆g etkilere değinilecektir.

\section{Sa'di-yi Şîrâzî'nin Yolculukları ve Gülistân}

656/1258 yılında yazılan "Gülistân" eserinin "Dîbâce" kısmında münâcât, na't, Ebû Bekir Sa'd b. Zengî”ye övgü ve “Gülistân"ın yazılma sebebi dile getirilmiştir.

Sa'dî bu eserin yazılma sebebi kısmında, dolaşmak ve zaman geçirmek için dostlarından biriyle şehrin uzağında bulunan bir bahçeye gittiklerinden ve orada konakladıklarından bahsetmiş̧ir (Enverî 1384: 35). Dönmeye karar verdikleri sabah arkadaşının kucak dolusu gül, reyhan, sümbül ve fesleğenle geldiğini gören Sa'dî, bahçedeki gülün bekâsının olmayacağını söyleyerek kalıcı bir Gülistân kitabı yazmaya karar vermiştir. Bu kararın da aslında kısa bir yolculuk sonrası alınmış olması "yolculuk" temasının eserin yazılmasında etkili olduğunu göstermektedir. 
Sa'dî'nin hem "Bûstân" hem "Gülistân" eseri, eğitim için gittiği Bağdat ile başlayan ve Dünya'nın çeşitli ülkelerine yaptığı yolculuklarının mahsulüdür.

Sekiz bölümden oluşan "Gülistân"ın birinci bölümü "Padişahların Hayat Tarzı" hakkındadır. Bu bölümde hem geçmişteki padişahların hem de gezdiği yerlerde karşılaştığ 1 önemli şahsiyetlerin halka kötü davranmalarını eleştirmekte ve hikâyelerinde işlemektedir.

Bu bölümün onuncu hikâyesinde, Şam'da bulunan Dımeşk Camii'nde insafsızlığı ile tanınan Arap kral ile Sa'dî bir araya gelmiştir. Arap kral, çetin bir düşmandan endişe ettiğini söyleyerek Sa'dî'nin duasında kendisini gönlünden geçirmesini istemiştir. Sa'dî ise krala, düşmandan kötülük görmemesi için önce halka eziyet etmemesi öğüdünde bulunmuştur (Şîrâzî 2013: 29; Şîrâzî 1392: 24).

Sa'dî'nin hem tarihte yaşananlar hem de gezip gördüğü yerlerde anlatılanlarla birlikte bizzat tanık olduğu olaylar da devletle ilgili görüşünde etkili olmuştur ve bunun sonucunda devlet düşüncesi şu şekilde tezahür etmiştir:

"Ona göre halkın padişaha olan ihtiyacından çok, padişahın halka ihtiyacı vardır. Padişah olsun

olmasın halk (riâya) yine halktır, ama halk olmadan bir padişahın varliğı düşünülemez ve bu

imkânsızdır" (Şahinoğlu [t.y.]: 113).

Bu tezi kanitlayacak dörtlüğü Sa'dî'nin "Gülistân" eserinde geçen bir dörtlükte de görmekteyiz (Şîrâzî 1392:23):

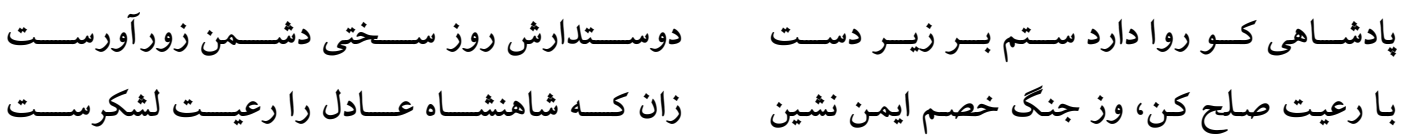

Padişah elindekilere zulmü reva görünce

Sevdikleri zor gününde onun güçlü bir düşmanı olur

Halkla barış, düşmanın savaşından güvende otur

Çünkü halk adaletli padişaha ordudur.

“Gülistân"ın ikinci bölümü "Dervişlerin Ahlâkı" hakkındadır. Bu bölümde Sa'dî'nin çıktığ1 yolculuklarda karşılaştı̆̆ dervişlerin nasıl olması gerektiğine dair hikâyeler yer almaktadir.

Bu bölümün ikinci hikâyesinde Sa'dî, Kâbe'nin eşiğine başını koymuş bir derviş görmekte ve kusurları için Allah'a yakarışını dile getirmektedir. (Şîrâzî 2013: 60; Şîrâzî 1392: 39). Bu hikâyede Sa'dî, kulun Allah'a karşı koşulsuz teslimiyetini şu sözleriyle göstermektedir (Şîrâzî 1392: 39):

$$
\text { (... به دريوزه آمده ام نه به تجارت. اضْنَعْ بَى ما آَنْتَ اَهْلُهُ.) }
$$

“...Ticarete değil dilenmeye geldim. Sen bana kendi şanına göre davran.”

SEFAD, 2018 (40): 61-72 
Sa'dî'nin ülkesi Şîrâz'dan ayrıldıktan sonra kutsal topraklara yolculuk ettiğini hayatı hakkında verilen bilgilerden elde etmekteyiz. Bu hikâyesinde de Kâbe'de ibadet ederken şahit olduğu bir olayı okuyucuya aktarmaktadır. Allah'a yakın olma yolunda çabalayan dervişin diğer kullar gibi günahsız olmadığı ve Allah karşısında tüm kulların da eşit olduğu şu dörtlükle ifade edilmektedir (Şîrâzî 1392:39):
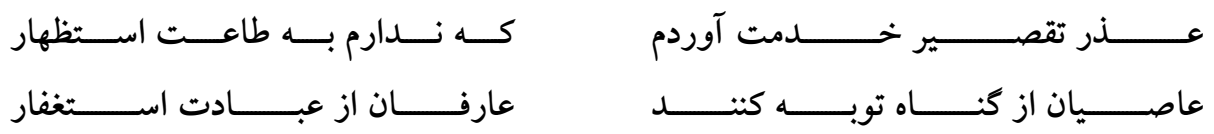

Hizmetteki kusurum için özür dilemeye geldim

Çünkü ibadetime yok güvenim

Âsiler günahtan tövbe ederler

Âriflerse ibadetten istiğfar ederler (Şîrâzî 2013: 60)

Beşinci hikâye, Sa'dî’nin adını zikretmediği bir yolculuğu üzerinedir. Bu hikâyede Sa'dî, dervişlerden oluşan bir gruba katılarak onların arkadaşlığından faydalanmak istemiş; fakat olumsuz bir cevap almıştır. Nedeni ise dervişlerin güveninin salih kılığına giren bir hırsız tarafından sarsılmasıdır. Hırsızın dış görünüşüne bakarak onu aralarına alan dervişler artık selametin teklikte olduğu görüşündedirler. Hikâyenin sonunda Sa'dî, dervişlerin arkadaşlığından faydalanamasa bile sohbetlerinden nasiplenmenin mutluluğunu yaşamıştır ve bu vahim olayın kendisi için de nasihat niteliğinde olduğunu dile getirmiştir (Şîrâzî 2013: 62-64; Şîrâzî 1392: 40-41).

Her kişiden yeni şeyler öğrenmeyi seven Sa‘dî, doğru bildiği şeyleri savunduğu gibi hayata dair tecrübeler de edinmekte ve düşünce dünyasını bunlarla beslemektedir. $\mathrm{Bu}$ hikâyede de başa gelen yanlış bir hareketin insanlardaki güven duygusunu ortadan kaldırdığı mesajı verilmektedir. İnsanların dış görünüşüne bakarak aldanılmaması asıl önemli olan şeyin ruh güzelliği olduğu şu beyitle vurgulanmaktadır (Şîrâzî 1392:40):
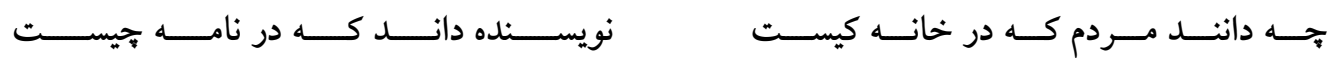

Ne bilsin insanlar elbisenin içinde kim var?

Yazan bilir ancak mektupta ne var?

Onuncu hikâye, Lübnan yolculuğu sırasında gittiği Baalbek Camii'nde geçmektedir. Sa'dî, vaaz verirken topluluk tarafından dinlenmemektedir; fakat söylediği sözlerin meclis dışından biri tarafından anlaşılması ve o kişinin nara atması ile herkesin dikkatini Sa'dî̀nin sözlerine çekmesi anlatılmaktadır (Şîrâzî 2013: 67-68; Şîrâzî 1392: 42). Bu noktada Sa'dî'nin bu yolculuğunda halka vaaz verdiğini görmekteyiz. Bu vaazlar bazen nasihat bazen de uyarı niteliğindedir. Bu bakımdan vaaz veren birinin eğitime önem verdiği düşünülebilir ve Sa'dî'nin de çıktığı yolculuklar esnasında halka doğruları en yalın haliyle aktardığı, dinleyici kitlesi iyi oldukça bilginin nesilden nesile geçeceğine inandığ1 söylenebilir (Şîrâzî 1392: 42): 

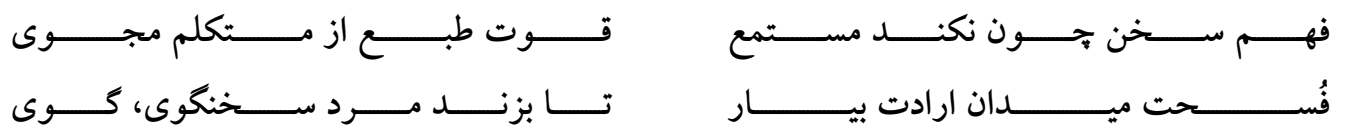

Dinleyici sözü anlamadığında

Konuşmacı da kuvvet arama

Konuşmacının topa vurması için

İsteklilik meydanını geniş tut

On birinci hikâye Mekke çölünde geçmektedir. Bu hikâyede hem dönemin zor şartlarına hem de Sa'dî'nin bu yolculuklar esnasında çektiği sıkıntılara değinilmektedir. Artık yorgunluktan bitap düşen Sa'dî başını koyup uyumaya çalışırken bir devecinin onu ikâz etmesi anlatılmaktadır (Şînâzî 2013: 68; Şîrâzî 1392: 42-43); çünkü geçtikleri o yol hiç tekin değildir ve her an ölümle karşı karşıya bulunmaktadır. Bu yolculukta olduğu gibi birçok yolculuğunda da Sa'dî, tehlike ile yüz yüze gelmiştir. Hem yaklaşan Moğol tehlikesi hem de o dönemin siyasî hayatı da göz önünde bulundurulduğunda yaşadığı sıkıntılı süreç Sa'dî'nin devamlı yer değiştirmesine neden olmuştur. Bu durumu bir kasidesinde şu şekilde dile getirmiştir (Şîrâzî 1392: 419):
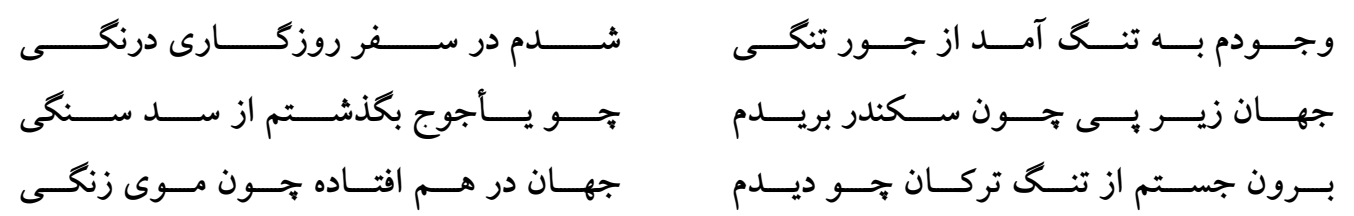

Bedenim sıkıntıdan usandı

Belli bir süre yolculuğa çıtım

Dünyayı İskender gibi ayağımın altına aldım

Ye'cûc gibi de taş seddi geçtim

Dünyanın zenci saçı gibi dolaştığını görünce

Türkler geçidinden çıktım gittim

Yirmi altıncı hikâye Hicâz yolculuğu sırasında geçmektedir. Sa'dî bu yolculuğu esnasında kendisine yoldaş olan bir gruptan, sonra aralarına katılan onlara şarkı ile eşlik eden Arap kabilesinden siyah bir çocuk ile âbitten söz etmektedir. Hikâye, âbitin topluluğun derdinden habersiz olduğu halde onların hâline itiraz edince Sa'dî'nin esprili bir şekilde Arap çocuğun şarkısının âbitin devesine etki ettiğini fakat kendisine etki etmediğini söylemesi ile son bulmaktadır. (Şîrâzî 2013: 78; Şîrâzî 1392: 47). Bu durum, Sa'dî'nin yolculukları esnasında rengi, dili ve mezhebi farklı olan insanlarla bir araya geldiğini göstermektedir; Hiç kimseyi kimseden üstün ya da aşağı görmeyen Sa'dî, önemli olan şeyin güzel huy ve ahlâk olduğunu okuyucuya anlatmaktadır (Şîrâzî 1392: 47):
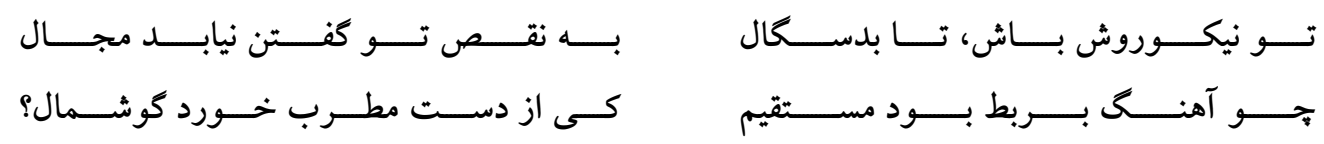

SEFAD, 2018 (40): 61-72 


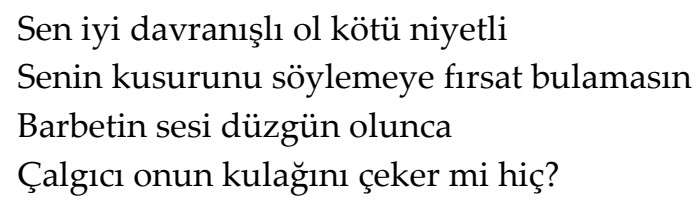

Otuzuncu hikâye, Sa'dî'nin Şam'daki dostlarından sıkılmasını, Kudüs çölüne düşmesini ve sonrasında Frenklere esir olmasını anlatmaktadır. Bu durum, Suriye'de bir liman şehri olan Trablus'ta bulunan bir hendekte çamur işine tabi tutulan Sa'dî'nin yolculukları esnasında her türlü tehlike ve olumsuzlukla karşı kaşıya kaldığının bir örneğidir. Bu hikâyede Sa'dî önceden tanıdığı Halep ileri gelenlerinden biri tarafından on dinar karşılığında esaretten kurtulmuştur; fakat bu kişi Sa dî ile kızını yüz dinar mihirle nikâhlamıştır. Sa'dî, kızın kavgacı ve itaatsiz olması yüzünden huzurunun bozulduğundan bahsetmektedir (Şîrâzî 2013: 81). Bu durumu Sa'dî, mesnevisinde şu şekilde anlatmaktadır (Şîrâzî 1392: 49):
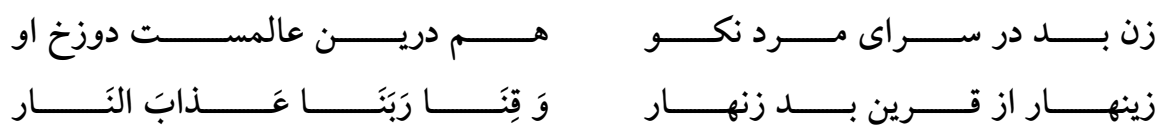

İyi adamın evindeki kötü kadın $\mathrm{Bu}$ âlemde onun cehennemidir Kötü arkadaştan zinhar uzak dur Rabbimiz, bizi cehennem azabından koru

Bu hikâyede, kaynaklarda hayatı hakkında fazla bilgi bulunmayan Sa'dî'nin başından mutsuz bir evliliğin geçtiği bilgisine ulaşılmaktadır; fakat Ziyâ Muvahhid'e göre: "Gülistân" bir sanat eseridir. Bu sadelikteki sanat eserlerinin mazmunlarından hayat hikâyesi çıkarılamaz (Muvahhid 1392: 39).

“Gülistân”ın üçüncü bölümü “Kanaatin Fazileti” hakkındadır. Sa'dî’nin bu bölüme verdiği addan da anlaşıldığı üzere kişinin elinde olanla yetinmesi, başkasının malına göz dikmemesi gerektiği vurgulanmaktadır. Dervişlerin mizacı üzerine hikâyelere de yer verilmiştir. (Avcıoğlu 2018: 128). Buna örnek olabilecek beyit şu şekildedir (Şîrâzî 1392: 57):

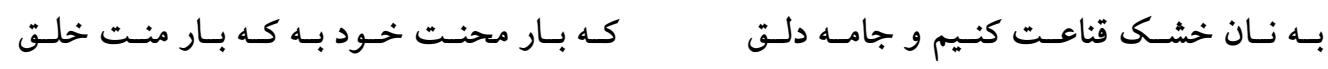

Kuru ekmek ve hırkayla yetinelim

Kendi mihnet yükümüz halkın mihnet yükünden iyidir

Bu bölümün on üçüncü hikayesi İskenderiye'de geçmektedir. Fakir bir grupla zengin arasında geçen bir olay anlatılmaktadır. Bir grup fakir, zengin hakkında uygunsuz laflarda bulunan Sa'dî’ye zenginin davetine gitmeyi uygun görüp görmediğini sormaktadır ve Sa‘dî’nin cevabı “uygun görmüyorum” şeklindedir (Ş̂râzî 2013: 102; Şîrâzî 1392: 60). 
Hikâyede geçen zenginin eli açık, vicdanlı ve dürüst olmadığını düşünen Sa'dî, başkasının malında gözü olmayan fakirin gerçek fakir hem dünyayı hem de ahireti elde eden zenginin ise gerçek zengin olduğunu beyan etmektedir (Şahinoğlu [t.y.]: 98). Oysa bu hikâyede, zengin ve fakir olan iki zıt karakteri ele alarak acizliğin yanlış bir davranış olduğunu mesnevisinde geçen şu beyitle vurgulamaktadır (Şîrâzî 1392: 60):
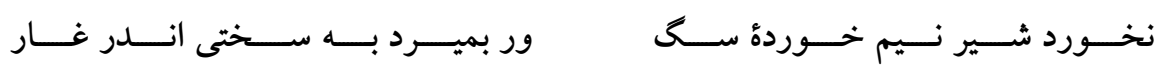

İninde sıkıntıdan ölse bile

Aslan köpeğin artığını yemez

Yirminci hikâyesinde Sa'dî, Irak'ta bulunan Kûfe Camii'ne yalın ayak girdiğini belirtmektedir. Ayağı olmayan birini görünce de hâline şükretmektedir. Bu hikâye ile Sa'dî'nin zor şartlar altında uzun yolculuklar yaptı̆̆ı anlaşılmaktadır; çünkü bu şartlar altında ne ayakkabı almayı düşünecek durumdadır ne de onu alabilecek gücü vardır. Sa'dî yalın ayak kalışını bu zamana kadar yaşadığı en zor olaylardan birisi olarak değerlendirmektedir (Şîrâzî 2013: 106; Şîrâzî 1392: 62). Ayağ1 olmayan birini görmesi ile de şükretmenin önemini ve Allah'ın verdiği ile yetinmeyi şu dörtlükle vurgulamaktadır (Şîrâzî 1392: 62):

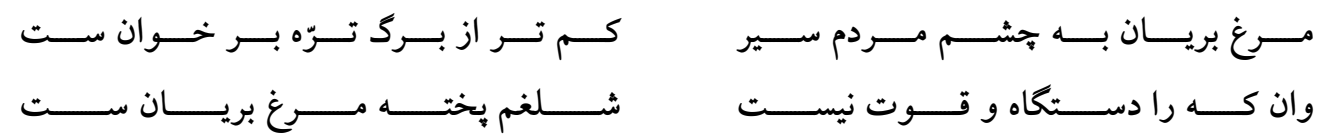

Tok insanların gözünde kızarmış tavuk

Sofradaki tereyağından kıymetsizdir

Durumu iyi olanlar içinse

Pişmiş şalgam kızarmış tavuktur

"Gülistân”ın beşinci bölümü "Aşk ve Gençlik" hakkındadır. Sa'dî’nin bu bölümde yer alan hikâyelerinde genel olarak sevginin her şeyin üstünde olduğu anlatılmaktadır. Âşık ile mâşuk arasında karşılıksız sevgi vardır. Sa'dî'ye göre ister padişah ister köle olsun âşık kişinin gözü hiçbir şey görmez (Avcioğlu 2018: 136). Bu bölümdeki bir hikâyede geçen şu dörtlük bu durumu açılar niteliktedir (Şîrâzî 1392: 82):
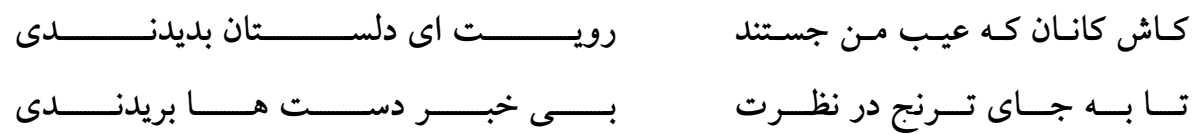

Benim kusurumu arayanlar keşke

Ey sevgili senin yüzünü görselerdi

Böylece seni görünce turunç yerine

Fark etmeden ellerini keserlerdi (Şîrâzî 2013: 148)

SEFAD, 2018 (40): 61-72 
Bu bölümün on altıncı hikâyesinde Doğu Türkistan'daki Kaşgar Camii'nde bir çocukla Sa'dî arasında dil bilgisi terminolojisi üzerine şaka yollu bir diyalog geçmektedir (Şîrâzî 2013: 144-146; Şîrâzî 1392: 80-81):

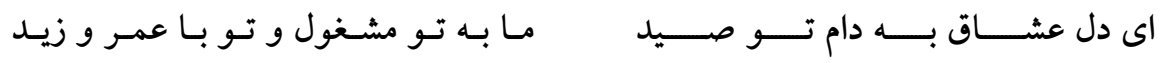

Ey âşıkların gönlü senin tuzağına av oldu

Biz seninle, sen ise Amr ve Zeyd ile meşgulsün

$\mathrm{Bu}$ çocukla ilgilenmesi ve çocuğa kendisini şair olarak tanıtmaması Sa'dî’nin hem mütevazı kişiliğini hem de çocuk sevgisini ön plana çıkarmaktadır. Sa'dî’nin hikâyelerinden her yaştan insana hitap ettiği, insanı dış görünüşü, yaşı ya da konumu ile değerlendirmediği sonucuna varılabilmektedir. Bu hikâyede olduğu gibi her yolculuk Sa'dî’nin farklı bir yönünü okuyucuya göstermektedir.

On yedinci hikâye Hicâz kervanında geçmektedir. Hırsızların ansızın kervana saldırması sonucunda tacirlerin feryat etmesi; fakat eşyaları çalınan dervişin hiç istifini bozmamasından bahsedilmektedir. Derviş ve Sa'dî arasında geçen diyalogda da üzülmemek için hiçbir şeye gönülden bağlanılmaması nasihat edilmektedir. Bu konuşma esnasında gençliğinde geçen bir olayı aktaran Sa'dî́nin bir gence gönülden bağlandı̆̆ı ve onu kaybedince nasıl büyük bir boşluğa düştüğü anlatılmaktadır (Şîrâzî 2013: 146; Şîrâzî 1392: 81). Hayatta hiçbir şeyin kalıcı olmadığına inanan Sa'dî, bir kişiye körü körüne bağlanmanın insana üzüntüden başka bir şey vermediğini şu dörtlükle ifade etmektedir (Şîrâzî 1392: 81):

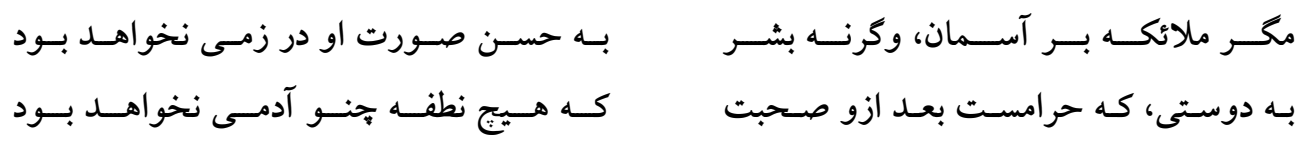

Yoksa gökyüzündeki melek mi? yeryüzünde

Onun yüz güzelliğinde insan var olmayacak

Onun sevgisinden sonra aşk haramdır

Çünkü hiçbir nutfe onun gibi bir insana dönüşmeyecek

“Gülistân"ın altıncı bölümü "Zayıflık ve İhtiyarlık" hakkındadır. Genel olarak bu bölümde hayata dair nasihatler bulunmaktadır. Birçok nimetle dolu hayatta nefes alıp vermenin bile bir nimet olduğu; fakat her güzel şey gibi bu rengarenk ömrün de hızlı bir şekilde son bulduğu anlatılmaktadır (Şîrâzî 2013:161; Şîrâzî 1392: 86):
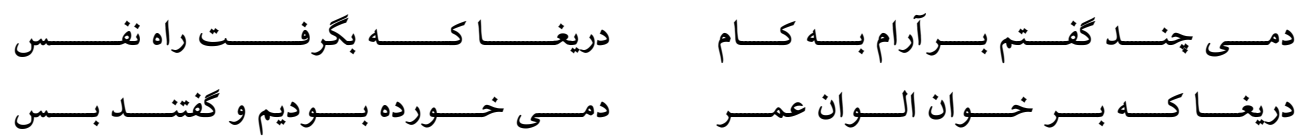

Bir süre keyfimce nefes alayım dedim

Yazık nefes yolum tıkandı 
Yazık renkli ömür sofrasında

Bir süre yedik ve yeter dediler

Bu bölümün birinci hikâyesinde Sa'dî ilim adamlarından bir grup ile Dımaşk (Şam) Camii'nde tartışmaktadır. O sırada bir genç, ölmek üzere olan bir ihtiyarın sadece Farsça bilmesi üzerine Sa'dî'den yardım istemektedir. Sa'dî de yardım etmeyi kabul edip yaşlı ihtiyarın dediklerini Arapçaya tercüme etmektedir (Şî̂âîi 2013: 155; Şîrâzî 1392: 86). Bu durum Sa'dî'nin Arapçaya da hâkim olduğunu göstermektedir. Aynı zamanda yardım etmenin önemine de değinilmektedir.

Üçüncü hikâye, Diyarbakır'da geçmektedir ve Sa'dî'nin yolculukları arasında Anadolu'ya da uğradığını göstermektedir. Burada bir ihtiyarla aralarında konuşma geçmektedir. Bir babanın oğlu için dilediği güzel temennilere karşı oğlunun babasının ölmesini istemesi anlatılmaktadır (Şîrâzî 2013: 158 ; Şîrâzî 1392: 87). Bu hikâyede hayatta kime ne edersen sen de onu görürsün mesajı verilmektedir. Bu hikâyeden Sa'dî'nin eski geleneğe bağlı olduğu görülmektedir; çünkü Sa'dî’ye göre hikâyede baba karakteri kendi babasını ziyaret etseydi oğlu da babasını ziyaret eder ve saygı duyardı.

"Gülistân"ın yedinci bölümü "Eğitimin Etkisi" hakkındadır. Bu bölümde genel olarak bir kişinin içinde cevher varsa aldığı eğitimin ona fayda sağlayacağından bahsedilmektedir.

Bu bölümün dördüncü hikâyesi Mağrip'te geçmektedir. Şahit olduğu bir olayı aktaran Sa'dî asık suratlı takvasız bir hocanın öğrencileri dövmesi üzerine yerine iyi huylu bir hocanın gelmesinden ve melek yüzünü gören öğrencilerin şeytan olup çıkmasından bahsetmektedir. Sa'dî hikâyeyi eski hocanın tekrar göreve getirilmesini kendisinin bile tasvip etmemesine bir ihtiyarın verdiği karşılıkla bitirmektedir (Şîrâzî 2013: 165; Şîrâzî 1392: 91). Aslında hikâyedeki ihtiyarın verdiği cevapla Sa'dî'nin olaya bakışı değişmektedir. O da iyi bir eğitimin ancak sert mizaçlı bir hocayla olabileceği düşüncesine varmaktadır.

On ikinci hikâye hacca yürüyerek giden bir grup arasında geçmektedir. O grubun içinde bir kavga çıkmakta ve Sa'dî de o kavgaya karışmaktadır. Etrafta oturan bir zat tarafından ise bu durum yadırganmaktadır (Şîrâzî 2013: 171; Şîrâzî 1392: 94). Sa'dî, burada her ne kadar kavganın içinde olsa da yapılanın yanlışlığını o zatın sözleri ile dile getirmektedir; çünkü Sa'dî, mizacı gereği kimseyle gereksiz diyalog ve tartı̧̧maya girmemektedir. Yolculukları esnasında birçok karakterdeki kişiyle karşılaşması, içinde bulundukları ortamın zorluğu bazen onu istemediği diyalogların içine sürüklese de Sa'dî bu durumlardan da ders çıkararak okuyucuya nasihatte bulunmaktadır.

On yedinci hikâyede Sa'dî, Bâmyân-Belh'ten çıktığı yolda harami tehlikesine karşı kendilerini koruyan bir gençten bahsetmektedir; fakat bu gencin güçlü ama tecrübesiz olması nedeniyle düşman karşısında eşyalarını bırakıp canlarını zor kurtarmışlardır (Şîrâzî 2013: 174; Şîrâzî 1392: 95). İkinci ve üçüncü bölümlerde değindiğimiz hikâyelerde olduğu gibi bu hikâyede de Sa'dî'nin çıktığı yolculukların can güvenliği zaafiyeti içinde çetin şartlar altında geçtiği dile getirilmektedir. 


\section{SONUÇ}

İran'ın en büyük şairleri arasında adından bahsettiren Sa'di-yi Şîrâzî XIII. yüzyılda yaşamıştır ve doğduğu yer olan Şîrâz'ı bölgenin içinde bulunduğu karışıklık nedeniyle iki defa terk etmek zorunda kalmıştır. Uzun yolculuklara çıkmış ve bu yolculuklardan edindiği tecrübeleri “Gülistân" eserinde okuyucuya aktarmıştır.

Sa'dî’nin hikâyelerinde dile getirdiği olaylardan ders çıkardığı gibi ders aldığı da aşikârdır. Her karşılaştığı insan, tanık olduğu ya da olmadığı olaylar onun düşünce dünyasında önemli etkiler bırakmışır; çünkü bu durum sayesinde kimi zaman olaylara karşı düşünceleri değişmiş kimi zaman da sahip olduğu fikirlerin doğruluğunun sağlamasını yapmıştır. "Gülistan"da ikinci bölümün beşinci hikâyesinde, yedinci bölümün dördüncü hikâyesinde Sa'dî, olaylardan ders çıkardığını zikrederken beşinci bölümün on yedinci hikâyesinde başından geçen bir olayla adetâ kendi düşüncesinin doğruluğunu kanıtlamıştır.

Bağdat ile başlayan yolculuk zincirine yenilerini ekleyerek zor şartlar altında değişik milletlerin âdet ve geleneklerini gören Sa'dî yeri geldiğinde dervişlerin mekânında bulunmuştur yeri geldiğinde ise çölde zor şartlar altında hayat mücadelesi vermiştir. Bunu "Gülistân"da ikinci bölümün beşinci hikâyesinde, beşinci bölümün on yedinci hikâyesinde ve ikinci bölümün on birinci hikâyesinde görmekteyiz.

Şînâz'a döndükten bir süre sonra bölgedeki asayişin bozulması nedeniyle tekrar şehri terk eden Sa'dî Bağdat'a, oradan da hac için Mekke'ye gitmiştir. Dönüşte Tebriz'e uğramış ve önemli şahsiyetlerle bir araya gelmiştir. Bu durum Sa'dî'nin her kesimden insan ile rahatlıkla iletişim kurabildiğini ve sözüne itibar edilen kişiliği nedeniyle de her mecliste yer alabildiğini göstermektedir.

Bu hikâyelerden bazıları bizzat tecrübe ettiği olaylar bazıları ise hayal ürünü hikâyelerdir; fakat hepsi didaktik şekilde kaleme alınmıştır. "Gülistân" eserini yaptığı uzun yolculuklarla süsleyen Sa'dî̀yi bazen nasihat veren bir bilge bazen ders veren bir hoca bazen de uyarıda bulunan bir dost olarak görmekteyiz.

Tüm bu bilgiler doğrultusunda bu çalışmada, "Gülistân" eserindeki 16 hikâyede Sa'dî’nin yolculukları saptanmış ve analiz edilmiştir. Özellikle Sa'dî’nin yolculuk esnasında adını zikredip orada bulunduğunu gösteren hikâyeler incelenmiştir. Bu hikâyelerinde geçen olayların Sa'dî'nin düşünce dünyasına dolaylı ya da doğrudan etkileri üzerinde durulmuştur. Bu etkileri de devlet anlayışı, insanların ahlâkı, sevgi, yaşlılık ve eğitim konularında görmek mümkündür.

\section{SUMMARY}

"Gülistân", one of the most important works of Sa'di-yi Şîrâzî, was written in 656/1258. This work, which consists of eight chapters, is different from Sa'dî's other works in terms of style and content due to the intertwining of verses and prose.

"Gülistân" was taught in the madrassas in the Ottoman period since it was a didactic work and translated into Turkish and several other languages many times.

Sa'di had to leave Şîrâz' twice because of the confusion in the region. He went on long journeys and shared his experiences gained in these journeys with his readers in his work “Gülistân". 
"Gülistân" is an important work in terms of presenting anecdotes from Sa'di's life and transferring the experiences he has gained to the reader. Most of the stories in "Gülistân" are about the experiences that the poet gained from the events and people during his journeys.

Some of these stories are the stories that he himself experienced; others are fictitious stories; but they were all written didactically. We can see Sa'dî, who adorns his "Gülistân" with his long journeys, sometimes as a scholar who gives advice, sometimes as a tutor who teaches and sometimes as a close friend.

Just like a dervish who travelled to many countries, Sa'dî came together with people whose color, language, and sectarian were different and he never considered people superior or inferior than the others.

Sa'dî added new ones to his travel chain starting in Baghdad and he experienced the customs of different nations. He was in the places of dervishes when appropriate and he sometimes tried to survive in a desert under harsh conditions.

When the chapters of "Gülistân" is examined, the traces of the journey can be seen. In the stories taking place in the first chapter of "Gülistân", the events that Sa'dî himself had witnessed in the places he visited and the history of those places were effective on his opinion about the state. He also severely criticized the cruel sultans he saw in the places he visited.

In the second chapter of the work, there are stories about how the dervishes Sa'dî met in his journeys should be like. It is stated that even the dervishes who are trying to be close to Allah are not sinless like all other servants and that all the servants are equal in the presence of Allah.

In the third chapter of the work, it is emphasized that people should be content with what they have and they should not covet the property of others. Sa'dî declares that the poor who does not covet someone else's property is the real poor, and the rich who obtains both the world and the hereafter is real rich.

In the fifth chapter of the work, it is generally explained that love is above all. It can be concluded from the stories told in this chapter that Sa'dî addresses people of all ages and does not evaluate human with its appearance, age or position. As in this story, each journey shows a different aspect of Sa'dî to the reader.

In the sixth chapter of the work, it is stated that even breathing is a boon in life with lots of other blessings; however, this colorful life ends quickly as well as many other good things.

In the seventh part of the work, it is mentioned that if a person has a superior ability, the education that he receives will benefit him. Although he encounters many people with different characters during his journeys in the stories of this chapter and the difficulty of their environment drags him into unwanted dialogues, Sa'dî takes lessons from these and advises the readers.

In this study, the journeys of Sa'dî in 16 stories of "Gülistân" were determined and analyzed. Especially the stories mentioned by Sa'dî during his journey and those showing he was there were studied. It is possible to see these influences on the concept of state, people's morality, love, old age and education. 


\section{KAYNAKÇA}

Avcıoğlu, Gamze Gizem (2018). Sa'di-yi Şîrâzî'nin Hayatı, Eserleri ve Türk Edebiyatındaki Yeri.

Doktora Tezi. İstanbul: İstanbul Üniversitesi, Sosyal Bilimler Enstitüsü.

Beyânî, Şîrîn (1388). "Zindegî ve Rûzigâr-i Sa 'di". C.III. Dânişnâme-yi Zebân ve Edeb-i Fârsî. Tahran: 19-20.

Dânişpejûh, Minûçihr (1388). Ustâd-i Suhen Sa'dî. Tahran: Neşr-i Hemşehrî.

Enverî, Hasan (1384). Şûrîde ve bî-Karâr der Bâre-yi Sa'dî ve Âsâr-i Û. Tahran: Neşr-i Katre.

İmdâd, Hasan (t.y.). "Seferhâ-yi Sa'dî”. No.2. Sa'dî Şinâsî, Şîrâz: 67-73.

Muvahhid, Ziyâ (1392). Sa'dî, Tahran: İntişârât-i Nîlûfer.

Safâ, Zebîhullâh, (1372). Târîh-i Edebiyyât-i Îrân. C.II. Tahran: İntişârât-i Firdevs.

Şahinoğlu, M. Nazif (t.y.). Sa'di-yi Şirazî ve İbn Teymiye'de Fert ve Cemiyet İlişkileri. İstanbul: İşaret Yayınları.

Şîrâzî, Sa'dî (1392). Kulliyyât-i Sa'dî. der. Muhammed 'Ali Furûgî, Tahran: İntişârât-i Semîr.

Şîrâzî, Sa'di (2013). Gülistan. çev. Hicabi Kırlangıç. İstanbul, Kapı Yayınları.

Şîrâzlı Şeyh Sa’dî (2011). Gül Suyu Gülistân Tercümesi. çev. Niğdeli Hakkı Eroğlu, (haz. Azmi Bilgin-Mustafa Çiçekler). İstanbul: Kurtuba Kitap.

Yazıc1, Tahsin (1966). “Sa'di”, İslam Ansiklopedisi C.X. İstanbul, M.E.B. Basımevi: 38.

Zerrînkûb, 'Abdulhuseyin (1343). Bâ Kârvân-i Hulle. Tahran: İntişârât-i Âryâ.

Zerrînkûb, 'Abdulhuseyin (1386). Hadîs-i Hoş-i Sa'dî. Tahran: İntişârât-i Suhen. 